DOI https://doi.org/10.30525/978-9934-26-085-8-1

\title{
ENGINEERING STRUCTURES OF UNDERGROUND TRANSPORT INFRASTRUCTURE
}

\author{
Avramenko Yu. O., Zyhun A. Yu.
}

\section{INTRODUCTION}

The urgency of parking in large cities is not in doubt. The growing population of city has created many problems one of the challenging ones being car parking which we confront almost every day. Besides the problem of space for cars moving on the road, greater is the problem of space for a parked vehicle considering that private vehicles remain parked for most of their time. While residential projects still escape with designated parking, the real problem lie with commercial spaces many a time which is overcome by taking extra open spaces and underground to park. Parking is one of the major problems that are created by the increasing road track. It is an impact of transport development. The availability of less space in urban areas has increased the demand for parking space especially in areas like Central business district. All too often cities suffer from too many cars and too few parking spaces. Effective parking management can help reduce congestion and expand the space on the roads.

\section{Determination of the trends and rules for the design of parking}

The automobile has an important role to play in the urban transportation system. As a result, parking is an essential piece of infrastructure in the built environment. Yet, cities are continually challenged to find ways of integrating parking into their fabric that are efficient, compact, attractive and ecologically sensitive. A key reason for this is that structured parking and/or underground parking is extremely expensive to construct and maintain and as a result large areas of surface parking prevail.

Standards or theirs sections are used for design can be divided into:

- Parking standards for residential developments - The overall intention of the standards is to ensure that subject to road capacity considerations; future residential developments should have sufficient parking provision to match the car ownership of residents.

- Parking standards for community facilities - The provision of parking for community facilities should generally be limited to 
operational requirements. Users of community facilities will generally be expected to use public transport or public car parks. However, for certain major GIC facilities such as cultural/recreational complexes which are of territorial significance, there may be a need to provide sufficient parking spaces commensurate with the nature of such facilities.

- Parking standards for commercial facilities - The overall intention of the standards is to ensure that, except in special circumstances, future commercial developments should have sufficient on-site parking to match manifest operational requirements.

- Parking standards for industrial and business developments - The overall intention of the standards is to ensure that sufficient parking and loading/unloading spaces are provided to satisfy requirements.

In all cases, the level of provision in a development is to be decided by the Authority. The standards serve to provide a guideline on which the Authority will base the decision.

The challenge of managing surface parking cannot be viewed in isolation. Rather, this challenge is inextricably linked to broader city building aims; intensifying commercial developments and reducing urban sprawl, building strong downtowns and urban centers, enhancing the public realm and providing the community with a range of mobility options. As a result, city builders will benefit from seeing this challenge holistically, working at various scales and with diverse stakeholders to adopt mutually reinforcing land use, transportation and parking strategies.

In the world there is an interesting organization ITDP - Institute for Transportation and Development Policy. The Institute works with cities worldwide to bring about transport solutions that cut greenhouse gas emissions, reduce poverty, and improve the quality of urban life.

Cities throughout the world, primarily in developing countries, engage ITDP to provide technical advice on improving their transport systems. ITDP uses its know-how to influence policy and raise awareness globally of the role sustainable transport plays in tackling greenhouse gas emissions, poverty and social inequality. This combination of pragmatic delivery with influencing policy and public attitudes defines our approach. Most recently, ITDP has been instrumental in designing and building the best bus rapid transit systems in the world.

ITDP focuses on the following program areas:

- Climate \& Transport Policy

- Cycling \& Walking

- Outreach \& Awareness

- Public Transport 
- Sustainable Urban Development

- Traffic Reduction

ITDP has offices in Argentina, Brazil, China, India, Indonesia, Mexico, and the United States; employs more than 60 staff members; and supplements this team with leading architects, urban planners, transport experts, developers, and financiers ${ }^{1,}$.

The Institute has its own library of standards and norms as well as the reports of the work performed. ITDP's publications support our work implementing sustainable urban development around the world. ITDP produces a range of materials for use by governments, industry professionals, and the public. Reports provide a focused look at the impacts or potential of programs and policies, often in a specific region, city or neighborhood ${ }^{2}$.

Work that I got interested it is "TOD standards", "Harbin Daoli Parking Report", "U.S. Parking Policies: An Overview of Management Strategies", "Parking Guidebook for Chinese Cities", "Parking and travel demand management policies in Latin". These reports identify core sustainable parking principles and illustrates how smarter parking management can benefit consumers and businesses in time and money savings, while also leading to more livable, attractive communities. There is a growing realization that the dysfunction caused by poorly conceived parking policies is a major impediment to creating an effective and balanced urban transportation system, it is also a significant cause of traffic and air pollution. These articles will help to see the steps, tactics for resolving the problems of cities. Provide an opportunity to see the results of these tactics and tips to improve transport infrastructure. Using the lessons from international best practices, gives advice to the pursue a mix of parking policies that harmonize all aspects of the transportation system and better manage all existing parking spaces, both on- and off-street.

For example, in the article "Parking Guidebook for Chinese Cities" talking about the fact that for years, the primary approach to parking has been to address perceived parking shortages by requiring developers to increase (free or low-priced) supply commensurate with the level of

${ }^{1}$ Harsha V., Karmarkar O., Verma A. Sustainable Urban Transport Policies to Improve Public Transportation System: A Case Study of Bengaluru, India. Transportation Research Procedia. Vol. 48, 2020. P. 3545-3561.

2 Marsden G., Reardon L. Questions of governance: Rethinking the study of transportation policy. Transportation Research Part A: Policy and Practice. Vol. 101. 2017. P. 238-251. 
development. Many cities now recognize this strategy as a failed approach. In light of the evidence, parking is now recognized as a powerful tool for affecting traffic speed, mode choice, urban density, urban design, quality of life and a host of related issues with impacts on the built environment, the natural environment and equitable access to opportunities. As Chinese cities recognize that parking policy affects these broader policy areas, they are seeing the problems of their traditional approach. Many are beginning to recognize that far from solving their parking and traffic problems, increasing parking supply and requiring developers to meet minimum parking thresholds has exacerbated the very problems they are trying to solve. For years, the primary approach to parking has been to address perceived parking shortages by requiring developers to increase (free or low-priced) supply commensurate with the level of development. Many cities now recognize this strategy as a failed approach. In light of the evidence, parking is now recognized as a powerful tool for affecting traffic speed, mode choice, urban density, urban design, quality of life and a host of related issues with impacts on the built environment, the natural environment and equitable access to opportunities. As Chinese cities recognize that parking policy affects these broader policy areas, they are seeing the problems of their traditional approach. Many are beginning to recognize that far from solving their parking and traffic problems, increasing parking supply and requiring developers to meet minimum parking thresholds has exacerbated the very problems they are trying to solve.

This guidebook looks at international strategies from many regions where parking has been tackled in a variety of ways. It offers recommendations that can be adopted in any Chinese city experiencing increased motorization and perceived parking shortages. The guidebook offers eight strategies for cities to improve their parking situation. These recommendations illustrate how handling on-street and off-street parking in harmony with transportation policy objectives can help any city achieve its long-term goals. A special section focusing on Guangzhou serves as a case study of one particular Chinese city coming to grips with how to approach growing motorization and the seemingly unyielding demand for parking in the best possible way. This guidebook looks at international strategies from many regions where parking has been tackled in a variety of ways. It offers recommendations that can be adopted in any Chinese city experiencing increased motorization and perceived parking shortages. The guidebook offers eight strategies for cities to improve their parking situation. These recommendations illustrate how handling on-street and 
off-street parking in harmony with transportation policy objectives can help any city achieve its long-term goals. A special section focusing on Guangzhou serves as a case study of one particular Chinese city coming to grips with how to approach growing motorization and the seemingly unyielding demand for parking in the best possible way ${ }^{3}$.

There are things which are not described by these articles and norms. It's kind of parking themselves, their design and architectural solutions and etc.

In an interesting article "Parking, People, and Cities Michael" Manville and Donald Shoup, this study of how off-street parking requirements affect urban form, we begin by analyzing the relationship between population density and streets in cities. We find that denser cities devote a greater share of their land to streets, but also have less street space per person. This relationship results in part from the difficulty of constructing new streets in built-out areas. The amount of street space does not increase as fast as population density, and this in turn helps explain why dense areas have less vehicle travel per person but higher levels of congestion. In contrast to streets, new off-street parking is supplied continually, owing largely to minimum parking requirements that make new development contingent on the provision of parking spaces. But the ample supply of off-street parking makes traffic congestion worse and inhibits street life. We recommend either removing off-street parking requirements, or converting them from minimums to maximums.

In her conclusions the interplay of population density and the share of land devoted to automobiles are more complex than advocates and even many academics suggest. Of the entire automobile infrastructure in an urban region, parking is the most dynamically supplied. Urban highways, even in their heyday, were infrequently built; today they are barely built at all. Streets are constructed more often, particularly in fast-growing areas, but the amount of road space in cities, and especially their cores, does not change very much. Parking, however, is constructed on a regular basis ${ }^{4}$.

Article "A Model of Parking Choice and Behavior" five Chinese scientist's help to expose the problem of choosing the best spot for parking. Pre-trip parking choice can be simplified to two kinds of choices:

${ }^{3}$ Drivers facing. 250-a-year tax to park at work despite pledge to end war on motorists. Daily Mail Online.

${ }^{4}$ Scheiner J., Faust N., Helmer J., Straub M., Holz-Rau C. What's that garage for? Private parking and on-street parking in a high-density urban residential neighborhood. Journal of Transport Geography. Vol. 85. 2020. 
choosing a parking space and selecting a travel route. When neither pretrip nor is en-route parking information provided, drivers typically search for parking spaces based on their previous parking experience. At a given point in time, this search could have three outcomes. Drivers could be:

1) parked after reaching destination;

2) still looking for parking at destination;

3) stuck in traffic on the way.

Inefficient parking searches can significantly increase traffic congestion, decrease environmental quality, and lower productivity. A solution to more efficient parking is to use pre-trip parking information through internet, mobile phones or other information technologies. A scientific parking choice model should therefore be developed to jointly manage traffic and parking information, calculate optimal choices, and distribute the resulting information to users. This paper aims at developing a parking choice model for pre-trip parking guidance systems that can assist drivers seeking optimal parking and travel routes in terms of availability, distance, safety, convenience, cost, and accessibility. To simulate the search of available options and then deciding among them, we propose a two-phase parking choice model ${ }^{5}$.

The proposed parking choice model considered factors that significantly affect parking choice behavior. Drivers' preferences are taken into account by assigning different weights to different factors. In addition, by modeling parking choice behavior using a two-phase procedure (identifying alternatives and then making a decision), our model not only simulates real-world parking decision-making, but it also shortens the search process and provides drivers with timely advice. In general, the proposed model can reduce search time for parking spaces and it can make a more efficient usage of existing parking facilities.

The model presented above optimizes parking and route choice at the user level rather than at the system level. However, system optimization is essential for improving the transportation system. Further research addressing system optimization is very much needed.

In the Australian article "Underground Car Park and South Lawn" is Conservation Management Plan for the Underground Car Park and South Lawn at the University of Melbourne's Parkville campus has been commissioned by Property and Campus Services at the University of Melbourne. The South Lawn, which conceals the Underground Car Park

${ }^{5}$ Mladenović M., Delot T., Laporte G., Wilbaut C. A scalable dynamic parking allocation framework. Computers \& Operations Research. Vol. 125. 2021. 
below, is the largest open space at the Parkville campus, and is the central component of a pedestrian precinct at the heart of the University. The Underground Car Park and South Lawn were conceived at the same time as a combined solution to two long-standing problems: on campus car parking and the poor quality of the existing South Lawn (sometimes referred to as the Main Quadrangle). Both were outcomes of the University of Melbourne Master Plan Report (1970), which recommended that a single-level car park, either underground or under a podium, be constructed in the center of the campus, and that the roof of the structure be made available for pedestrian access.

This article describes the stages of construction and reconstruction of underground parking. Analyzes the factors that influence these processes. That gives advice to the landscape design of the parking area. The following Conservation Policy and Management Plan is informed by the preceding assessment of the cultural heritage significance of the Underground Car Park and the South Lawn (the study area) and its associated western embankment, and has been developed with an understanding of:

- the values and cultural significance of the place as a whole, and the relative levels of significance of its individual built, landscape and arboricultural elements;

- the condition and physical constraints and qualities of the study area;

- statutory and other constraints.

These matters are addressed under the relevant policies ${ }^{6}$.

Review of the current literature, which is used in the construction of parking leads to the following conclusions:

1. In Ukraine there is a major standard in this area, which covers many issues - DBN B.2.3-15-2007 "Transport facilities. Car parks and garages for cars". These Standards apply to the design of new and reconstruction of existing parking lots and garages regardless of the form of ownership and departmental affiliation and are mandatory for all organizations, associations, individuals who have the appropriate license and carry out their design and construction, as well as projects for customers and organizations that coordinate and maintain project documentation. There is still some amount of domestic documents that are

${ }^{6}$ Pike D., Jolly C.K., Pundsack M., Stewart J.N., Whapples W. Design recommendations for multi-storey and underground car parks. London: Institution of Structural Engineers, 2011.98 p. 
required when designing parking. But with the increasing number of vehicles, you need to update standards and to use the same old rules.

2. In the present design must pay attention to disabled people. In Ukraine, there are rules that you want to use in the regeneration of special places for them. This norm - is DBN B.2.2-40:2018 - "Inclusive buildings and structures".

3. It is important when considering of this question is fire safety and ventilation. In our country there are many rules that control this issue. One of the most important of these, in my opinion, is DBN B.1.1.7-2016 "Fire safety of construction objects". These rules set fire classification of construction materials, construction, fire barriers, exterior fire stairs and staircases, buildings and structures of buildings and general requirements for the safety of people in case of fire, fire safety design and spaceplanning decisions, equipment, buildings, facilities engineering and technical means of protection against fire.

4. Standards for areas like the previous Soviet Union may be different minor features. In other countries, there are many regulations that normalizing this issue and have significant differences. Often standards in the world designed for a specific city or region.

5. In the world there is an interesting organization ITDP - Institute for Transportation and Development Policy. The Institute works with cities worldwide to bring about transport solutions that cut greenhouse gas emissions, reduce poverty, and improve the quality of urban life. On their basis there is a lot of work on this topic.

6. The purpose and objectives of the research. Purpose of the work is analyzing new technologies; principles address issues in the transport sector, which is used in the world. Making an analysis of the transport infrastructure in the city of Poltava and offer solutions to current issues.

To achieve this goal, it is necessary to solve the following problems:

- Analysis of modern transport infrastructure;

- Analysis of technical documentation, regulatory documents, summary and comparison;

- Structural analysis and planning interesting decisions that embodiment at a life;

- Analysis of the main requirements for the design of parking and errors that arise in the design. 


\section{Basic requirements for the design of parking}

Parking is the act of stopping and disengaging a vehicle and leaving it unoccupied. Parking on one or both sides of a road is often permitted, though sometimes with restrictions. Parking facilities are constructed in combination with some buildings, to facilitate the coming and going of the buildings' users.

In our cities, the vast majority of private cars located in the courtyards of houses, and unfortunately, often on green lawns and recreation areas. This, above all, worsens the living conditions of the population. Cars also left on the roadway streets, making it difficult to city traffic, it becomes one of the causes of accidents. Such "parking" occupies large areas urban territory, spoiling the appearance of cities. At the present time storage of cars belonging to citizens in districts and residential areas provided the construction of garages without maintenance and repair, and industrial utility and storage areas with maintenance. To organize garages, use the sanitary - protective zones of industrial and agricultural enterprises, as well as railways. In districts and residential areas garages placed in specially designated areas with the organization of these visits to the streets and local roads or on the main streets of the district values. Progressive trend in solving the problem of storage of private cars is the construction of multi-story garage and cooperative - fairing ${ }^{7}$.

Parking is the act of stopping and disengaging a vehicle and leaving it unoccupied. Parking on one or both sides of a road is often permitted, though sometimes with restrictions. Parking facilities are constructed in combination with some buildings, to facilitate the coming and going of the buildings users.

Currently in the world there have been three main areas of problem solving closed parking: by building new garages, add-existing placement of garages in the reconstruction of industrial buildings.

There is an opinion that it is possible a significant reduction in the cost of erection of garages, and thus reducing the market value of parking garages in the existing superstructure, as well as placing the garage complexes in reconstructed, unfinished, abandoned industrial buildings.

To develop optimal architectural and construction solutions parking ramp is advisable to use an integrated approach in the design, consisting of the following:

- to minimize the flow of usable area parking for one car is necessary to consider several options for space-planning decisions;

${ }^{7}$ Kodransky M., Spring G. Europe's Parking U-Turn: From Accommodation to Regulation. Inst. Transp. Dev. Policy. Vol. 15. 2011. 
- optimization of accommodation garage on a dedicated site for development of urban areas requires an examination of several options for the master plan development;

- to reduce the consumption of materials, duration and cost of the construction of parking ramp is necessary to consider several options for constructive solutions.

In addition to the options under consideration can further evaluate the architectural expression and color palette appearance garage. These points are important in the design of multi-storey car parks ${ }^{8}$.

Parking as part of an overall transportation system is one of the crucial issues of our times. As the number of automobiles increases exponentially, the need to house them in close proximity creates a challenging design problem.

All parking can be divided for different principles.

Table 1

\section{Classification parking}

\begin{tabular}{|c|c|}
\hline $\begin{array}{l}\text { Accommodation } \\
\text { in the urban } \\
\text { environment }\end{array}$ & $\begin{array}{l}\text { - In the area of objects citywide importance urban } \\
\text { development (social, sporting, cultural, shopping } \\
\text { centers, railway stations, airports, etc.); } \\
\text { - In utilities and other non-residential areas; } \\
\text { - In a residential area, including regional, yard; } \\
\text { - In the area of urban transport (squares, } \\
\text { - streets, interchanges, bridges). }\end{array}$ \\
\hline $\begin{array}{c}\text { For the duration } \\
\text { of storage }\end{array}$ & $\begin{array}{l}\text { - Permanent storage; } \\
\text { - Temporary storage; } \\
\text { - Seasonal storage; }\end{array}$ \\
\hline $\begin{array}{l}\text { By placing the } \\
\text { objects relative } \\
\text { to another } \\
\text { destination }\end{array}$ & $\begin{array}{l}\text { - Stand-alone; } \\
\text { - Attached; } \\
\text { - Built-in; } \\
\text { - Combined; }\end{array}$ \\
\hline $\begin{array}{l}\text { By placing the } \\
\text { level of land }\end{array}$ & $\begin{array}{l}\text { - Aboveground; } \\
\text { - Underground; } \\
\text { - Combined; }\end{array}$ \\
\hline
\end{tabular}

${ }^{8}$ Subhan M.D. Analysis and Design of a of Multi-Storey Car Park Complex. International Journal of Advanced Technology and Innovative Research. Vol. 08. № 03. 2016. P. 495-499. 
Completion of Table

\begin{tabular}{|c|l|}
\hline $\begin{array}{c}\text { By number of } \\
\text { floors }\end{array}$ & - Storey; \\
\hline $\begin{array}{c}\text { By way of } \\
\text { moving }\end{array}$ & - Rultistory; \\
interstorey & - Rechanized; \\
\hline By the & - Foyer; \\
organization of & - Box; \\
storage & - Valium; \\
\hline $\begin{array}{c}\text { By type of } \\
\text { enclosing } \\
\text { structures }\end{array}$ & - Combined; \\
\hline $\begin{array}{c}\text { Under the terms } \\
\text { of storage }\end{array}$ & - Copen; \\
\hline
\end{tabular}

The parking facility or lot must foremost deal with the Functional/ Operational - as in providing for safe and efficient passage of the automobile. This is a very complex challenge as automotive, engineering and traffic issues relative to site locations must be integrated to create the appropriate solution. Therefore designing the parking facility requires an integrated design approach of many professionals. Parking has often been reduced to the construction of the most minimal stand-alone structure or parking lot without human, aesthetic or integrative considerations. This has given parking a poor public perception and has frequently disrupted existing urban fabric. However, many architects, engineers, and planners have envisioned and constructed far more complex, aesthetic, and integrative structures. This should be the goal of good parking design.

Although parking facilities can take many forms as stand-alone or part of a mixed-use structure, self-park or valet, and automated in urban settings, all parking facilities should seek to meet the following basic criteria:

\section{Functional Requirements}

The facility should account for the complex spatial needs of the driver and the automobile:

- The size, height, and turning radius of current automobiles as well as past and future trends of automobile size and statistical quantity must be taken into account these are called parking geometries. 
- There are many ramp design configurations and different ones are appropriate for the primary purpose of the facility to insure that your intended use is compatible with ramp design.

- The streets surrounding the facility and their traffic flow must be taken into consideration when planning entrances and exits and deciding on ramp designs.

- The entrances and exits are very important to the smooth functioning of the facility, with the type of use again determining the length from the opening and placement of the entry booths, as well as the quantity of entrances and exits.

- Zoning issues require the number of spaces for parked automobiles. The designer must work within local codes to meet these requirements.

- In mixed-use projects there has been shared parking documenting how different users can maintain full facility occupancy, such as movie/theater goers, night use and residential use during the day. This can be calculated to the advantage of the facility owner and the community by eliminating the empty night facility syndrome.

- Optimizing site potential, by choice of site and its relationship to walking, driving, other transportation linkages and good design opportunities.

- The operation and maintenance of a facility is very critical. Revenue control equipment and other issues related to the smooth functioning of the garage must be taken into account during the design process.

- Provide for appropriate work space for the staff, such as cashier and monitoring equipment.

- Provide an area or room for the storage and maintenance issues. This area should be heated/air-conditioned and contain a mop sink.

- Accommodate technological tools for future upgrades of operational systems and facility expansion.

- Plan for a backup power system.

- Ventilation is an issue within some types and some areas of parking facility design. New technologies are increasing the effectiveness in design and monitoring of these areas for concern. Natural ventilation is always a good method however detailed study is required in some areas and types of parking facility design to determine its effectiveness.

Structural Integration

The efficient integration of structure is crucial to maximum functioning of the facility: 
- The parking facility is typically an exposed structure and must be designed to withstand all aspects of environmental conditions.

- There are ideal structural bays that allow for maximum number of parking spaces and flow of automobiles dependent upon site and structure.

- Cast in place concrete, pre-cast concrete and structural steel can be used for the structural design.

- Typical construction issues such as natural hazards in the location of construction apply and compound the solutions in designing a structure that is completely exposed to the weather and constant movement from automobiles.

- Size and length of some structures compound the expansion and contraction issues already of key importance in facility design.

- The surface of the "floor" of the facility is important to slippage issues as one must always design a facility as a fully exposed building for the safe use by both the automobile and pedestrian.

- In very cold climates ice, snow, salt and other road chemicals must be taken into consideration. Some facilities have snow chutes where snow can be plowed off of the top level of the structure. At minimum an area where snow can be piled must be designed into the structure or lot.

- Drainage and floor slope is very important, as pounding water can create long term maintenance problems.

Safety and Security

Safety and security of the people using the facility are of paramount importance:

- Open, glass stairwells and glass-backed elevators.

- Security devices such as video, audio and emergency buttons that call into the booth or local police station.

- Public telephones

- Eliminate potential hiding places, such as under open stairs.

- Handicap accessibility with vehicles close to stair and elevator cores having a direct path to key movement patterns of the facility.

- To avoid carbon monoxide build-up, air flow is adequately designed for through mechanical or natural ventilation.

- Non-slip floor surface

- Cleanliness

- Design for the points of intersection between man and the automobile for adequate safety of movement.

- Energy efficient lighting is very important in facility safety but can pose problems with spillage out of the facility onto neighboring 
communities. A balance between daylighting, interior lighting and exterior control can be addressed in many ways on the exterior design of the façade while providing adequate lighting within. Lights should be vandal resistant and easy to maintain.

- Use CPTED (Crime Prevention Through Environmental Design) whenever appropriate along with technological equipment.

- Signs and Wayfinding

- Color-coding, numbering, visual cues, music, and even machines for marking your ticket with your exact location to locate your car for easy retrieval

- Locate signs in areas where driver can read in a timely fashion.

- Clear, simple, and direct messages.

- Floor coding can be useful

- Signage should locate all major internal pedestrian access points as well as external major roads and buildings.

Aesthetics

Aesthetics of facility design has become very important to communities across the country:

- Recently facility design has become part of an architectural style of the surrounding architecture, respecting the language of design and using the design process.

- The historic preservation movement was one of the key issues in facility design as facilities were needed to revitalize dense older urban fabrics without destroying the architectural context. Many excellent examples can be found across the country solving these contextual issues.

- The Parking facility itself is now also part of the historic preservation movement as some older existing structures can and should be designated for preservation.

- The Parking Facility has played an important role in design evolution throughout its history often being the leader in many crucial design issues; it is truly a unique and important civic building. Perhaps one of the most important design laboratories of the 20th century it has become the gateway to our buildings and cities.

- Maintain the urban street front by having the sidewalk condition of the facility contain stores or provide a safe and pleasant walk experience.

- Using landscaping and changes in architectural materials forms, and scales to enhance the facility façade along the street. Use landscaping to shied and enhance parking lot design. 
- Architecturally breaking down the scale of the large structure along its façade.

- Designing beautiful stairs and elevator cores to enhance the community and walking experience.

- Most costly solution is to "hide" the facility by placing below ground .

When designing landscaping of settlements must comply with fire protection, sanitary and constructive, technological requirements, aimed at creating a favorable environment for human life, the preservation and protection of the environment, providing of sanitary and epidemiological welfare of the population.

\section{The requirements for hardscape}

The works of monumental and decorative art (sculpture and architectural compositions, monumental and decorative compositions, monuments, memorials, etc.) must be placed in residential areas by appropriate planning documentation. In order to be able to use areas of common use handicapped visually impaired hardscape should choose bright (contrast) tones or bright dyeing (contrast) colors.

To obtain vertical gardening should apply the following types of devices: trellis, wallpaper, pergolas, flower pots, vases.

Fountains, drinking fountains, springs, ornamental pond should provide spillway pipes that allocating excess water into the drainage network and storm sewers. Fountains are generally performed on the basis of individual projects or project solutions (design solutions) reuse. Decorative pond constructs using terrain or on a flat surface in combination with lawn, tiled covering, flower beds, trees and shrub plantings. The bottom of the pond should perform a smooth, easy to clean. Use the techniques of color and light design.

Installing benches provide typically hard to types of coverage or foundation. In recreation areas, parks, playgrounds bench set on "soft" types of coverage. If the foundation is prohibited his performance on the ground. The height of the bench for the rest of the adult level of coverage to the plane of the seat should be taken in the range from $0.42 \mathrm{~m}$ to $0.48 \mathrm{~m}$. The surface of the bench for the rest of the tree do with different types of waterproof processing (mostly - impregnation). Number of rows

${ }^{9}$ Szopinska-Mularz M., Lehmann S. Urban Farming in Inner-city Multi-storey Car-parking Structures-Adaptive Reuse Potential. Future Cities and Environment. Vol. 5 (1). 2019. P. 4. 
determines the number of seats depending on the load and the structure of the recreation area in accordance with Table $10^{10}$.

The number of small architectural forms shall be determined according to the functional purpose of the territory and the number of visitors to the area, using the following principles: ecology, safety (no sharp edges), ease of use, ease of cleaning, attractive appearance.

To collect domestic waste in the streets, squares, recreation facilities should be used bins, setting them at the entrance: the objects of trade and catering and other public institutions, subways, apartment buildings and transport facilities. On territory recreation objects should provide for the establishment boxes next addition benches, litter bins should be installed on the bus stops. In all cases, the installation of bins to be done so as not to obstruct the movement of pedestrians, wheelchair and travel strollers.

Installation of street technical equipment (ventilation shafts underground utilities, telephone service cabinets, etc.) should provide a convenient approach to equipment and comply with the requirements ${ }^{11}$.

Making elements of engineering equipment must not disturb the level of landscaping; worsen the conditions of travel, contrary to specifications, including:

- Manhole covers inspection pits located in the walkways and sidewalks should be designed, usually in the same level with adjacent surface coating, otherwise drop marks should not exceed $0.02 \mathrm{~m}$, and the gaps between the edge of the hatch and the pavement should not be more than $0,015 \mathrm{~m}$;

- Ventilation shafts shall be equipped with bars.

At the turn of the pavement and the roadway is usually necessary to establish road curbs of normative exceeding above the roadway at least $0.15 \mathrm{~m}$, which should be kept and if the reconstruction surface coatings. In order to protect the lawn and prevent dirt and plant debris to cover in case of a combination of pedestrian areas, walkways and sidewalks shall be mounted with lawn garden side, beyond the level of the lawn at least $0.05 \mathrm{~m}$ at a distance of not less than $0.5 \mathrm{~m}$.

${ }^{10}$ DBN B.2.2-12:2019. Planning and development of territories. Kyiv : Ministry of Regional Development, Construction and Housing and Communal Services of Ukraine, 2019. $185 \mathrm{p}$.

11 DBN B.2.2-40:2018. Inclusive buildings and structures. Kyiv : Ministry of Regional Development, Construction and Housing and Communal Services of Ukraine, 2017. 99 p. 
On the territory of pedestrian areas can use natural materials (brick, wood, boulders, ceramics, etc.) for connecting different types of coverage.

As for the fence, it must be distinguished by: purpose (decorative, protective, both), height (low - from $0.3 \mathrm{~m}$ to $1 \mathrm{~m}$ average - from $1.1 \mathrm{~m}$ to $1.7 \mathrm{~m}$ high $-18 \mathrm{~m}$ to $2.5 \mathrm{~m}$ ), the type of material (metal, concrete, etc.), the degree of permeability to view (transparent deaf), the degree of stationary (permanent, temporary, mobile). Designing protections should be performed depending on their place in accordance with the standards catalog of the certified products, individual design projects.

It is necessary to provide for placing protective metal fences height not less than 0.5 meters in places adjoining lawns to driveways, parking automobiles in areas of possible collision of cars on the lawn and trampling paths through the lawn. Enclosures must be placed in the lawn of a departure from the limits of adhesion from $0.2 \mathrm{~m}$ to $0.3 \mathrm{~m}$.

In the design of medium to high species fences in the intersection of design of underground structures include fences, which allow carrying out repair and construction work.

Basic requirements for the design of green spaces

In the settlement using different methods or forms of gardening: fixed (planting in soil), mobile (planting in special mobile containers: containers, pots, etc.), compact (vertical, tiered landscaping, etc.) and so on. When selecting species composition of green space should pay attention to the climatic and microclimatic conditions areas. Formation of the landscape must take into account the existing technology and anthropogenic pressures, followed by minimizing this impact by recreational properties of plants.

Green areas do not have to hover on footpaths. The branches of green space if they grow over walkways shall be not less than $2,1 \mathrm{~m}$. In the residential areas of a large area of built-up surfaces, high-density construction and underground utilities should be applied to mobile and compact planting techniques.

If planting trees in areas of heating should be considered a factor in warming the soil either side of the axis heating at a distance: the intense heating - $2 \mathrm{~m}$, medium - from $2 \mathrm{~m}$ to $6 \mathrm{~m}$, low - from $6 \mathrm{~m}$ to $10 \mathrm{~m}$ near the heating cannot be place: linden, maple, lilac, honeysuckle - closer than $2 \mathrm{~m}$, hawthorn, cotoneaster, sod, larch, birch - closer than 3-4 m.

During the formation of multi-tree and shrub plantings from the road should be planted plants resistant exhaust. In the mid strip preference should be given an evergreen woody plant with dense foliage, usually pine. 
Individual projects and flower beds should be done in the form of fragments in scale 1:100, 1:200 indicating the range, the number of seedlings per plant species and planting locations of each type. Demolition and replanting of trees, shrubs, lawns, flowerbeds carrying out only in the case of a special permit (order) and act inspection of green space (trees, shrubs, lawns, parks, forest parks, planting of sanitary protection zones) to be demolished or transferring in connection of buildings and manage land area. Green areas (trees and shrubs), demolished during the reconstruction and construction of new buildings and structures shall be compensated (compensatory planting).

\section{The requirements for coating}

For an accomplishment should use the following types of coverage:

- solid (capital) - monolithic or prefabricated executed on asphalt, cement-concrete, natural or artificial stone, etc.;

- "soft" (non-capital) - those that are made of natural or artificial granular materials (sand, gravel, granite bran, stone, rubber crumb, etc.) that are in their natural state or in dry mixtures, condensed or fortified binder,

- lawns - are executed by special technology training and planting grass cover;

- combination - a combination of coverage listed above (such as tile, drowned in the lawn, etc.).

Surface playgrounds and sports fields should be done with natural granular materials (sand, gravel, granite bran, etc.) lawn. Prohibited the use of crumb rubber, packing bulk binders and coating tiles these objects.

Type of coating used in improvement projects should be strong, rebuild able, ecological and prevent slipping.

Choosing the type of coverage should be carried out according to their purpose:

- Solid - with regard to the possible limit loads, the nature and composition of traffic, fire protection requirements;

- "soft" - taking into account the characteristics of individual areas (children, sports grounds, playgrounds for walking animals, walking paths, etc.);

- Lawn and combined - the most ecological.

Solid types of coverage should have a rough surface with a coefficient of grip in the dry state of at least 0.6 in the wet - not less than 0.4. It is forbidden to use as cover tile, tile, smooth or polished slabs of artificial and natural stones in the walkways and sidewalks on the ground and subways, on the steps of stairs, platforms wings entrance to buildings.

Inclined surfaces solid types of coverage shall provide drainage of surface water - the watersheds in the presence of rain water it should be 
not less than 4\%o, in the absence of rain water - not less than 5\%. The maximum slope shall be determined depending on the traffic and pedestrians, but not more than $8 \%(1: 12)$.

In the settlement all obstacles (ledges, steps, ramps, trees, lighting, information and street maintenance equipment, and curb zones and public transport crossing the street) must provide unified stripes and tactile contrast on the edge of coverage. Tactile coverage should begin at a distance of not less than $0.8 \mathrm{~m}$ to interference edge street, beginning a dangerous area, change the direction of motion and so on. If tactile surfaces are longitudinal groove width greater than $0,015 \mathrm{~m}$ and a depth of over 0,006 meters, they cannot be placed along the direction of motion.

For trees located in paving, in the absence of other forms of protection (trunks lattice borders, perimeter benches, etc.) for the enforcement of protective coatings species within not less than $1.5 \mathrm{~m}$ from the trunk: crushed stone, gravel, "cells" with seeded lawn. Sheeting performed above the cover walkways and sidewalks.

\section{CONCLUSIONS}

1. Review of foreign experience of management of the parking system identified key trends in this field. The main strategies for parking management fall into four categories: pricing mechanisms, regulatory measures, physical design elements, and quality of service contracting (and the advanced technologies that enable these four). These can be employed in different combinations to achieve different effects, so the best practices ultimately depend on the goals of the city implementing the policy.

2. Conducted in the work analysis showed that the complex development of underground space of the city is one of the effective areas of modern urban planning. The motivation for the "multi-level" development of the city is the exhaustion of urban areas for new construction and reconstruction of industrial and utility companies, transport and extension of utilities, loss of landscaping, reducing environmental pollution, increase the capacity of highways in the hours "peak", reducing road accidents, etc.

3. Insufficient number of parking lots in residential and central areas with established multi-storey buildings and their irrational accommodation at the city forcing car owners to park their cars in yard areas, reducing the safety and comfort of the living conditions of citizens as a consequence, the proportion of road accidents continuously increasing. Analysis of national and international research in the design of new and optimization of existing parking lots showed that at present method of determining the number of required parking spaces for parking lots located in dense urban areas needs to 
be improved in the development of new approaches to the calculation of the number of required parking spaces and determine a rational area car parks.

4. The parking facility or lot must foremost deal with the Functional/Operational task - as in providing for safe and efficient passage of the automobile. This is a very complex challenge as automotive, engineering and traffic issues relative to site locations must be integrated to create the appropriate solution. Therefore, designing the parking facility requires an integrated design approach of many professionals. Developed a method constructing underground parking. This corresponds to the current regulations.

5. To improve the efficiency of complex use of underground space in my degree work we reviewed the use of underground parking areas over the park. This proves that the construction of underground parking is a good truck resolving issues and problems greening the city. For external refining areas have been adopted and used such basic requirements as:

- The requirements for hardscape;

- Basic requirements for the design of green spaces;

- The requirements for coating.

\section{SUMMARY}

The progressive increase in the number of cars parked on the roadside and often on pavements has caused a significant decrease in the road space available to both moving vehicles and pedestrians. The construction of underground parking facilities has increasingly drawn attention as a solution for parking problems in urban areas. Many countries have adopted the option of underground car parks to overcome this problem. The primary advantage of this type of car park is that it can be developed in high-density urban areas where street-level space is at a premium. It is also hidden from view and can provide enhanced security and weather protection for vehicles.

\section{REFERENCES}

1. Harsha V., Karmarkar O., Verma A. Sustainable Urban Transport Policies to Improve Public Transportation System: A Case Study of Bengaluru, India. Transportation Research Procedia. Vol. 48. 2020. P. 3545-3561. URL: https://doi.org/10.1016/j.trpro.2020.08.097.

2. Marsden G., Reardon L. Questions of governance: Rethinking the study of transportation policy. Transportation Research Part A: Policy and Practice. Vol. 101. 2017. P. 238-251. URL: https://doi.org/10.1016/ j.tra.2017.05.008.

3. Drivers facing. 250-a-year tax to park at work despite pledge to end 'war on motorists. Daily Mail Online. URL: http://wvvw.dailymail.co.uk/ 
news/article-1305362/Driversfacing-25O-tax-park-work-despiteend-warmotoristpledge.html\#ixzzoxbWxYyko.

4. Scheiner J., Faust N., Helmer J., Straub M., Holz-Rau C. What's that garage for? Private parking and on-street parking in a high-density urban residential neighborhood. Journal of Transport Geography. Vol. 85. 2020. URL: https://doi.org/10.1016/j.jtrangeo.2020.102714.

5. Mladenović M., Delot T., Laporte G., Wilbaut C.. A scalable dynamic parking allocation framework. Computers \& Operations Research. Vol. 125. 2021. URL: https://doi.org/10.1016/j.cor.2020.105080.

6. Pike D., Jolly C.K., Pundsack M., Stewart J.N., Whapples W. Design recommendations for multi-storey and underground car parks. London : Institution of Structural Engineers, 2011.98 p.

7. Kodransky M., Spring G. Europe's Parking U-Turn: From Accommodation to Regulation. Inst. Transp. Dev. Policy. Vol. 15. 2011.

8. Subhan M.D. Analysis and Design of a of Multi-Storey Car Park Complex. International Journal of Advanced Technology and Innovative Research. Vol. 08. № 03. 2016. P. 495-499.

9. Szopinska-Mularz M., Lehmann S. Urban Farming in Inner-city Multi-storey Car-parking Structures-Adaptive Reuse Potential. Future Cities and Environment. Vol. 5 (1). 2019. P. 4. DOI: http://doi.org/ $10.5334 /$ fce. 50 .

10. ДБН В.2.2-12:2019. Планування та забудова територій. Вид. офіц. Київ : Мінрегіон України, 2019. 185 с.

11. ДБН В.2.2-40:2018. Інклюзивність будівель і споруд. Основні положення. Вид. офіц. Київ : Мінрегіон України, 2018. 99 с.

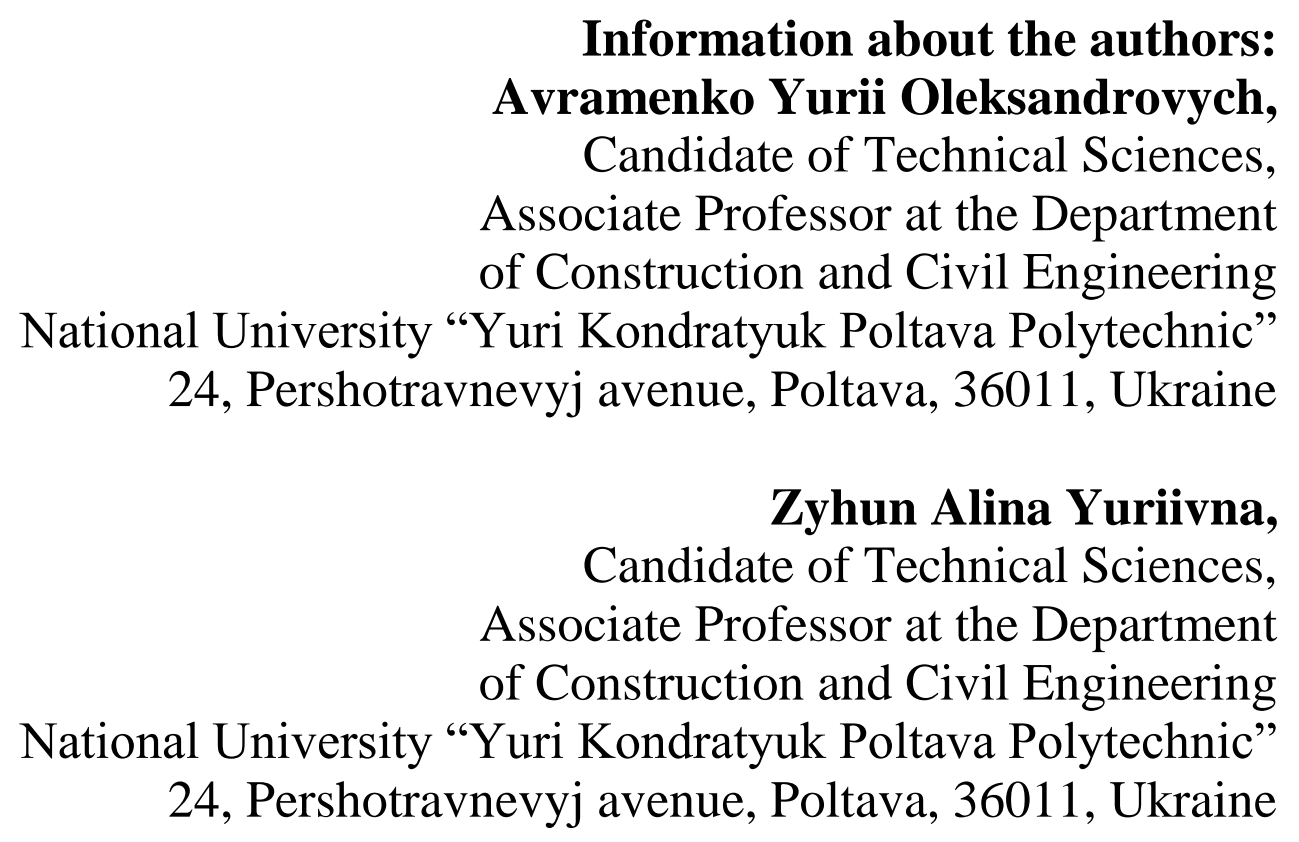

